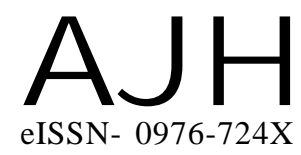

Article history :

Received : 19.10 .2015

Revised : 13.05.2016

Accepted : 20.05.2016

Members of the Research Forum

Associated Authors:

${ }^{1}$ Regional Fruits Research Station

(Dr.P.D.K.V.), KATOL (M.S.) INDIA

Author for correspondence :

S.M. GHAWADE

Chilli and Vegetable Research Unit,

Dr. Panjabrao Deshmukh Krishi

Vidyapeeth, AKOLA (M.S.) INDIA
THEASIAN JOURNAL OF HORTICULTURE

Volume 11 | Issue 1 | June, 2016 | 194-198

Visit us -www.researchjournal.co.in
DOI : 10.15740/HAS/TAJH/11.1/194-198

RESEARCH PAPER

\section{Effect of planting dates, bio-fertilizers and organic manures on qualitative horticultural characteristics of garlic}

\section{S.M. GHAWADE AND V.S. GONGE ${ }^{1}$}

ABSTRACT : A field experiment was carried out at the Main Garden, Department of Horticulture, Dr. Panjabrao Deshmukh Krishi Vidyapeeth, Akola during Rabi seasons of the years 2004-05 and 2005-06. The experiment was laid out in Split Plot Design with four replications and thirty treatment combinations. An early maturity of garlic crop was noticed with the $30^{\text {th }}$ October planting date and nutrient management treatment of $75 \mathrm{~kg}$ nitrogen $\mathrm{ha}^{-1}+37.5 \mathrm{~kg}$ phosphorus $\mathrm{ha}^{-1}+$ PSB @ $2.5 \mathrm{~g} \mathrm{~kg} \mathrm{ha}^{-1}$ of cloves. The cloves bulb ${ }^{-1}$, size of bulbs and cloves (diameters and length) were found to be the maximum with $15^{\text {th }}$ September planting date and nutrient management treatment of $50 \mathrm{~kg} \mathrm{ha}^{-1}+25 \mathrm{~kg}$ phosphorus ha ${ }^{-1}+$ vermicompost @ $5 \mathrm{t} \mathrm{ha}^{-1}$. In the storage study for 90 days the total soluble solids content in the garlic cloves did not show any significant differences.

KEY WORDS : Cloves, Biofertilizers, TSS

HOW TO CITE THIS ARTICLE : Ghawade, S.M. and Gonge, V.S. (2016). Effect of planting dates, biofertilizers and organic manures on qualitative horticultural characteristics of garlic. Asian J. Hort., 11(1) : 194-198, DOI : 10.15740/HAS/TAJH/11.1/194-198. 